Faculty of Humanities

Faculty Publications

The Liberal Party and the Achievement of National Medicare

P. E. Bryden

2009

(c) 2009. This is an open access article.

This article was originally published at:

https://doi.org/10.3138/cbmh.26.2.315

Citation for this paper:

Bryden, P. E. (2009). The Liberal Party and the achievement of national Medicare. Canadian Bulletin of Medical History, 26(2), 315-332. DOI: 10.3138/cbmh.26.2.315 


\title{
The Liberal Party and the Achievement of National Medicare
}

\author{
P. E. BRYDEN
}

\begin{abstract}
The process that led to the implementation of a full national health insurance system in Canada was as complicated and contested as the battles that were fought over Medicare in Saskatchewan. The federal Liberal party had to first adopt health insurance as a serious component of its electoral platform, devise a strategy for dealing with provinces which had constitutional jurisdiction over health, and finally wrestle with those within the party-and within the cabinet-who continued to question whether Canada was financially prepared to administer such a costly program. The strategies were devised and the battles were fought privately, but had an important effect on the timing and shape of a national health insurance system.
\end{abstract}

Keywords. Medicare, Liberal party, federal-provincial relations

Résumé. Le processus à l'origine de l'implantation d'un régime complet d'assurance maladie au Canada a été aussi compliqué et contesté que la bataille livrée pour l'obtention de soins de santé en Saskatchewan. L'aile fédérale du Parti libéral avait intégré à sa plate-forme électorale l'implantation d'un régime d'assurance maladie national, envisagé une stratégie pour négocier avec les provinces dont la santé est de juridiction provinciale et finalement proposé un débat avec les membres du parti et du cabinet. Toutefois, ces derniers remettaient en question les compétences financières du Canada pour administrer un programme aussi onéreux. Les stratégies élaborées et les débats, surtout privés, ont eu un effet important tant sur les échéanciers que sur la forme qu'a pris le régime national d'assurance maladie.

Mots-clés. Parti libéral, assurance maladie, relations fédérales et provinciales

P. E. Bryden, Department of History, University of Victoria. 
To understand the origins of government-funded medical care in Canada it is impossible to ignore the role played by successive administrations in Saskatchewan. Historians of that province have rightly emphasized the development of ideas of health insurance from their roots in agrarian populism and farmer militancy, through the organization of the municipal doctors scheme and the Swift Current model, to the now-legendary clash between Saskatchewan doctors and the state in the summer of $1962 .{ }^{1}$ Broader examinations of health insurance in the Canadian context have also paid close attention to the Saskatchewan model. ${ }^{2}$ This emphasis on the events in Saskatchewan, and in particular on the three-week strike by physicians following the passage of the Saskatchewan Medical Insurance Plan, is not surprising. The battle seemed particularly pitched in the prairie province, with clear heroes and villains - at least in retrospect-and widely reported coverage of events that allowed a national and even international audience to follow the action. The result of this attention to Saskatchewan, however, has been to ignore some of the other landmarks along the road to Medicare. A national program of health insurance was not achieved until 1968, itself the result of more than a decade of struggle within the federal Liberal party, first for control of direction of the party and then for control of the cabinet. The battle was certainly not as public as that fought between the Lloyd government of Saskatchewan and the striking doctors, but it was just as fierce.

$* * *$

The national health insurance system in Canada had a particularly long germination period, which perhaps explains why relatively little attention is paid to the final years leading up to its implementation. The Liberal Party was hobbled or blessed, depending on the circumstances, with a commitment to health insurance dating back to the leadership convention of 1919, and so the idea itself can be traced at least that far. ${ }^{3}$ There had been plenty of earlier interest in various forms of more localized health insurance. For decades prior, for example, individual communities had been pooling their resources to cover collective medical costs in an early form of health insurance. ${ }^{4}$ Mackenzie King, upon whom the leadership fell in 1919, claims to have first thrown out the idea in his magnum opus Industry and Humanity, although the same could be said of most of the policy decisions undertaken by his government in the next 30 years-and beyond! But before those ideas can take root and grow into actual pieces of legislation, they must find an agreeable conjunction of interests, and the Canadian environment proved less conducive to health insurance than the 1919 statement suggested.

The British Columbia government undertook the first serious attempt at state health insurance in the 1930s. The effect of the Depression on 
farmers and the resource-sector has been well-documented, but physicians servicing these constituencies also suffered from the patients' inability to pay. In some ways, the time seemed ripe for the introduction of at least provincially administered health insurance programs. Investigations were undertaken in all the western provinces during the 1930s. In BC, the Liberal government of Duff Pattullo sought imaginative solutions to the Depression, including the introduction of state-sponsored health insurance to cover the costs of caring for the growing number of indigent citizens. The doctors were at first delighted at the prospect of being paid for their services, but organized opposition soon began to develop. The Canadian Medical Association (CMA) was opposed to the constraints the BC legislation would impose on the choice of physician and its political power, combined with the declining fortunes of the Liberals in BC, led to the shelving of the legislation permanently in 1936. ${ }^{5}$ Provincial action in the field of health would have to wait until after the war.

The Rowell-Sirois Commission, undertaken in the dog days of the Depression and reporting in the early stages of World War II, noted the possibility of a national government assuming responsibility for expensive social security legislation like health insurance, although stopped short of actually recommending its implementation. The division of powers-with provinces responsible for most services but sharing the valuable tax dollars with the federal government-was the chief concern of the Commission. The interests of the day, and therefore those included in the Report, were most pressingly the provision of unemployment insurance, a system for equalizing the differences across the provinces, and a reconfiguring of the tax system to better reflect the distribution of responsibilities. ${ }^{6}$

But as the bleakest days of war in the spring of 1940 passed, and Canadians began to think seriously about how their lives would be reconstructed in its aftermath, governments also began to consider health insurance more seriously. Mackenzie King's Liberal government struck an advisory committee on health insurance, appointing in 1942 J. J. Heagerty, Director of Public Health Services, as chair. The Heagerty Report, as it came to be called, took into consideration the views of the medical community as expressed by the CMA during the British Columbia negotiations, but fell into the trap of not adequately addressing the concerns of other groups like those representing agricultural and labour. Once again, the various interests involved in the implementation of health insurance failed to align properly, and as a result, legislation failed to materialize. ${ }^{7}$

Health insurance was still a desirable goal for the federal government when it met with provincial representatives to hash out a national plan for postwar reconstruction. But the Green Book proposals presented at 
the Dominion-Provincial Conference on Reconstruction in 1945-46 tied the costly social security policies to a shift in tax powers that would see the provinces hand over control of the direct tax fields. Although this had been the approach followed during wartime, the coming of peace heralded to many a return to greater autonomy for the provinces. The premiers were unwilling to accept the tax arrangements, and so the social security offered by King's government fell off the table. ${ }^{8}$ Health insurance would again wait for a more agreeable political climate.

North American economic prosperity following World War II meant that some of the financial impediments to implementing national health insurance had been eliminated. The federal government was thus able to begin a slow and steady move towards full health insurance by first introducing health grants, followed a decade later by hospital insurance. ${ }^{9}$ These were baby steps. Clearly, the environment was not quite right for the implementation of full health insurance, despite there having already been important advances at the provincial level. In the mid1950s, premiers from British Columbia, Saskatchewan, Manitoba, and Ontario had all urged the federal government to provide some leadership in the field of health insurance, where there was "unquestionably a great deal of misunderstanding and confusion." 10 Ontario's Conservative Premier Leslie Frost laid out before the first ministers five alternatives for moving the state into the health care field, ranging from coverage of components such as home-care to full hospital coverage. But in pushing forward the intergovernmental agenda, and functioning as something of a spokesman for the other premiers, Frost was careful to propose a staged movement toward hospital insurance-itself only a step in the progression toward a full Medicare system. ${ }^{11}$ Even this proved difficult to achieve, with both Ontario and the federal government at one time or another doubting the details of the hospital insurance proposal. Nevertheless, hospital insurance made its appearance on the national political landscape in 1957, and slow but steady postwar progress can be seen to be being made toward the ultimate goal expressed by the Liberal convention in 1919.

Three things happened in the decade after the introduction of the Hospital Insurance and Diagnostic Services Act, 1957 that made it feasible for the Liberal Party of Canada to consider finally fulfilling its health insurance promise. Two of them-the successful introduction of health insurance in Saskatchewan, and the report of the Hall Commission on health services-have rightly received the most attention. ${ }^{12}$ Less attention has been paid to the power struggle within the national Liberal party itself, which occurred both in Opposition and again once they achieved power in the mid-1960s. These battles were necessary not only to create an environment within which the Liberals could consider health insurance, but also in determining what form that insurance would ultimately take. 
The third factor, then, in explaining the timing of the final national push to implement full health insurance, was the Liberal losses in the elections of 1957, 1958, and 1962, and the necessary reconceptualization of their policy priorities.

The initial shock of having lost power in 1957 was followed quickly by the more devastating electoral defeat of 1958 under the new leadership of Lester Pearson. After 22 years in power, the Liberals were unaccustomed to opposition, and many embarked on a period of partisan introspection. Numerous party members took a turn at trying to figure out what had gone wrong. The old guard tended to think the electoral misfortunes were because the party had veered from its "management" priorities and had tried to promise too much to a cynical electorate. The new recruits to the party, including people like Tom Kent and Walter Gordon, pointed instead to the need to develop those promises into concrete policy solutions. Over the course of six years in opposition, it was the new guard that came to prominence.

A renewed commitment to national health insurance took shape for the opposition Liberals in a number of different ways. Following the lead of other parties in opposition, the Liberals sponsored a non-partisan "thinkers conference" designed, in part, to infuse the party with new ideas. The Kingston Conference, as it came to be known, invited participants "to discuss the great national issues and to argue about what government policy should be with respect to these issues." 13 Among those issues was social security, where the discussion was expected to address the "reconciliation of individual liberty and responsibility, control over the public purse and taxation levels and the demands of a people getting used to the idea of a welfare state."14

Two of the papers given at the Kingston Conference dealt specifically with health insurance. Wendell Macleod, the Dean of Medicine at the University of Saskatchewan, delivered a discussion paper on "Basic Issues in Hospital and Medical Care Insurance." In it, he identified the issues that were even more pressing than how to administer and finance an insurance scheme, namely "what are the health expectations of the Canadian people? How are these likely to change in the foreseeable future? Are prevailing assumptions and conceptions sound? For example, in the various segments of our society what are the gaps between health expectations and health needs?" 15 His was a broad inquiry into the state of society and the place of health care provision within it. The inclusion of a Saskatchewan practitioner in this conference suggests that there was a general sense in central Canada that the prairie province had important advice to dispense regarding health care. Macleod's paper, however, ended up being more philosophical than prescriptive.

Tom Kent's paper, on the other hand, was designed to offer more pointed policy proposals for discussion. In "Towards a Philosophy of 
Social Security," he built on the theme that "freedom is not just the absence of constraint but, equally, the opportunity to act" by outlining an 11-point agenda for action. It included Medicare, whereby the federal "government should pay the individual's medical bills on a sliding scale related to income" and sickness insurance providing "the same level of income-maintenance for sick people as for those who are unemployed for other reasons." 16 Kent's goal was to stimulate discussion. One participant noted that Kent's "full-scale attack" was "very well received by the majority" although criticized by Frank Underhill for "importing ... Fabian socialism to a cold climate." 17 Regardless of the reception, however, Kent's paper clearly became a talking-point.

In order to ensure that the Kingston Conference ideas developed into positive policy goals, the Liberal Party established a policy committee that would massage the discussion points into resolutions. These then would be voted on at the party's Liberal Rally to be held early in 1961. The point of the Rally was "to stir up a general feeling of enthusiasm throughout the Party." 18 Walter Gordon was one of the members of the policy committee, and therefore instrumental in ensuring that ideas turned into workable policy alternatives. On the left of the party, he had been "very much impressed" with Tom Kent's proposals, and asked him "to put forward some specific suggestions about pensions and other forms of social security." 19

The Liberal "Plan for Health" was unveiled at the Liberal convention-the "Rally" — of January 1961. It offered a government-sponsored scheme for covering hospital, physician, drug and rehabilitation fees, according to an agreed-upon scale of fees. Precisely how such a program would be financed was left up in the air, although the plan floated a method "similar in principle to the present treatment of family allowance and old-age pensions" by which everyone received the benefit but the wealthiest essentially had the increase taxed back. ${ }^{20}$ The plan was a bit vague on specifics, but it was certainly successful in attracting attention at the Rally. Seventy people jammed the plenary session to join in the discussion about health insurance and by the end of the convention, a nine-point plan for health, based very closely on the original discussion paper, was endorsed by the party membership.

Yet it was still not sufficient to take to the electorate. The plan needed tweaking: in dealing with an issue that divided people, the Liberals needed to be careful not to alienate the centre while appealing to the reformers or vice versa. Pearson was clear about what would need to be done before the scheme could be unveiled for the public. Specifically, other interested parties needed to be consulted, including both the committee currently investigating health insurance in Saskatchewan and the Canadian Medical Association, and the question of how the plan was to be administered needed to be more explicitly addressed. ${ }^{21}$ 
Included in the group charged with making the health plan electionready were both Boyd Upper, who "got the impression that little of this material will catch the attention of the voter," and Tom Kent, who was staking his future in the Liberal party on the electorate's readiness for changes in the delivery of health and other social services. ${ }^{22}$

Between the Liberal Rally in January 1961 and the party's return to power in April 1963, it was the progressive, more interventionist approach to social policy that gained prominence in the Liberal platform. Boyd Upper's first attempt at drafting a memorandum on health services contained a number of features that the more reformist elements in the party found unacceptable. Universal availability was not to be weakened, as Upper had proposed, with the requirement of registering for the program. It was desirable, although not necessarily wise from a legislative standpoint, to avoid surcharges, another feature of the Upper plan. Furthermore, the reformers were clear that the Liberal agenda would not be driven by the objectives of the CMA, or by provincial priorities. Despite protestations that the Upper memorandum was "excellent," by the time Kent and Gordon had finished with it, it was a much more pointed statement of federal intentions in the health insurance field than the original document had envisioned. ${ }^{23}$ Significantly, it was the reformers, and not the more cautious people like Boyd Upper, who were key to revamping the Liberal fortunes.

Although it was difficult for the Liberals to content themselves with opposition after so many years of governing, the years between 1957 and 1963 were absolutely imperative for the development of social policies in general, and renewing a real commitment to national health insurance in particular. Electoral defeat brought home to party members too accustomed to power the need to revamp the Liberal platform. With first a thinkers' conference, and then a partisan convention, the Liberals were able to generate new social policy ideas or, in the case of health insurance, resurrect an old social policy idea and give it new life. Party officials like Kent and Gordon were then able to shape the resolutions into actual strategies to be employed in election rhetoric and beyond. By ensuring that the policy proposals had the support of the grassroots of the party, the officials were able to establish a place in electoral strategy for expensive programs such as national health insurance. Even after leaving office, with the achievement of Medicare already under his belt, Pearson was able to point to "the building of our Party in opposition; getting a new foundation and a new superstructure" as the accomplishment "that gave [him] more satisfaction than anything else as a political achievement." 24 Without the period in opposition, it is doubtful whether health insurance would have made it onto the Liberal agenda. 
Having won the struggle to direct the electoral approach of the Liberal party in opposition, the reformers could hardly rest on their laurels. The challenge of governing was vastly different from that of getting into power, and it was questionable whether those advisors and activists who had brought the Liberals to electoral success in 1963 would be the ones who would be dominant once the party reclaimed the reins of power. Some, like Tom Kent, continued to function in an advisory capacity. Whether that advice would continue to be acted upon, however, remained to be seen. Others, like Walter Gordon, sought elected office, and thus continued to fight for social reform from the cabinet room rather than the backrooms. While joined by other reformers, like Maurice Lamontagne, Judy LaMarsh and Allan MacEachen, there were powerful cabinet colleagues who argued for policies of restraint. Before national health insurance could become a reality, therefore, another internal power struggle was bound to ensue.

Despite the enthusiasm Liberals of all ranks had expressed for a national health insurance scheme, it was not the social policy with which they opened their return to government in 1963. Instead, a universal pension plan had moved to centre stage following its popularity on the floor of the Liberal Rally. The grassroots support, plus a sense in the halls of power that it would be more straightforward to implement than a health insurance plan, led to the inclusion of pension reform in the list of first steps to be taken by the new Pearson government. As Judy LaMarsh, the new minister of National Health and Welfare, later noted, pensions were "the thing to start with ... because [the program] would be self-funding and we didn't know how much money there would be to start Medicare." 25 Furthermore, by 1963 Saskatchewan had already introduced health insurance on the provincial level, and had been met with a hostile medical community that promptly went on strike. The province was only just beginning to recover from the doctors' strike; history had not yet cast the government as the dragon-slayer in this epic battle, and it was far from clear that the public was fully behind health insurance in Saskatchewan, let alone across the rest of the country. The Liberals in Ottawa chose a wait-and-see approach on health, while pressing ahead on their other social policy goal in the pension field.

Lessons learned during negotiations over pensions had an enormous effect on the shape of the national health insurance. Between 1963 and 1965, when the Liberals began negotiations with provincial premiers over health insurance, the pension scheme was unveiled by the federal government and then substantially revised in light of the appearance of a much more attractive plan in Quebec. Provincial governments proved sophisticated in their own policy planning, and unwilling to simply endorse a federal social program without debating questions of consti- 
tutional jurisdiction. The experience of attempting to introduce a social program that had clear provincial implications had a profound effect on the manner in which the Liberals approached health care negotiations. Although health raised a number of questions that were absent from the pension debates, there was enough similarity between the two programs that the strategies employed the second time around could benefit from the experience of the first round.

Despite clear evidence to the contrary, the new Liberal government seemed taken aback by the degree to which provincial governments had investigated pension reform. The national Liberals were certainly aware of the Advisory Committee on Portable Pensions that had been established by Premier Leslie Frost in Ontario in 1960, and continued its work under the new government of John Robarts. The Ontario Premier, despite being Conservative, had written to then Opposition Leader Mike Pearson in early 1962 that "I learn with much pleasure of your proposals to develop a contributory social security scheme for the aged." More than pleased, apparently-he was ready to see Pearson move into the prime minister's office: "the government of Ontario would concur in and facilitate proper and reasonable plans by your government resulting in a contributory social insurance program becoming a reality." 26 But the plan that was taking shape in Ontario was very different from the one the federal Liberals imagined. The chief distinction between the two schemes was that Ontario's portable, compulsory old age pension program would be run by the insurance industry; Ottawa's plan was to establish a government-sponsored program.

Clearly, the two levels of government were on a collision course. George Gathercole, the chair of Ontario's pension committee, fully backed by the insurance industry, demanded that the federal scheme conform to the shape of the Ontario plan. ${ }^{27}$ Equally stubbornly, the federal government prepared to force its own scheme onto reluctant provinces at a series of intergovernmental conferences. The first, in the fall of 1963, was clearly "dominated" by Ontario, as the federal delegation struggled to keep the upper hand. Federal officials tinkered with the pension proposals in the face of Ontario's well-conceived plan. The next major meeting, in the early spring of 1964, witnessed a bombshell from Quebec: the Quebec government had also devised a pension scheme which it would be implementing shortly and was considerably more generous than the one Ottawa was offering and more attractive in all ways to the Ontario scheme. ${ }^{28}$ Following this disclosure, Pearson and the Liberals were forced to backtrack, reshape the Canada Pension Plan in line with the Quebec Pension Plan, and begin an important re-evaluation of their approach to social policy.

Timing was everything. The group of left-leaning policy planners who had pushed health insurance to the front of Liberal consciousness 
while in Opposition were no longer quite as powerful as they used to be. The reformist cabinet ministers-notably Walter Gordon in Finance and Judy LaMarsh in Health and Welfare-had had their wings clipped, the former after a crisis in his first budget, the latter because of the gruelling pension debate. Those people behind the scenes like Tom Kent saw their influence wane, too, as the realities of government empowered those more likely to advise caution. So despite a strong commitment to health insurance in 1963, just one year later the resolve was shaken. The doctors' strike in Saskatchewan did not force action in Ottawa; nor did the investigations into private health insurance schemes in Ontario, Alberta and British Columbia. Only one thing could push the Liberals into action, and that was the report of the Hall Commission. When Volume 1 was released in the summer of 1964, and, amazingly, advocated a government-sponsored system of full health insurance, the Liberals could sit on their promises no longer. Hard-learned lessons in other fields would now determine the manner in which national health insurance was implemented.

Different people took different lessons from the first year or so of Liberal government. Kent thought that the federal government needed to lay out its plan for health insurance and then begin negotiations with the provinces; the experience of negotiating with the provinces over pensions had taught him the wisdom of being prepared. As he later explained to the Prime Minister, while the Conservatives thought "we ought to have worked out a national [pension] plan by agreement," the reality was that "it would have taken an indefinite time to get anywhere if we hadn't faced the provinces with firm proposals." 29 Kent argued for doing the same thing regarding health. Gordon, on the other hand, argued that "given the other complications we are going to have with the provincial governments" 30 in finalizing pensions, 1965 would be too early to take on health insurance. He also had "reservations about using Federal-Provincial relations as an excuse for an election," which he feared would happen if the next election was delayed. Essentially, Gordon thought the need for a united Liberal front on the health question was a good reason to head back to the polls quickly, hoping for a solid majority and the Parliamentary strength necessary to silence the conservatives in the party. ${ }^{31}$ Probably under pressure from her cabinet colleagues, LaMarsh went ahead with a different approach, and began soliciting the views of the provinces in the spring of $1965 .{ }^{32}$ Better to know what might lie ahead than to be caught completely off-guard as had been the case with pensions. Although preliminary discussions with provincial bureaucrats demonstrated a remarkable divergence of views, the prime minister was still optimistic in the summer of 1965 that moving forward with Medicare would indicate a "willingness to co-operate with the provinces." 33 There might be differences of opinion over strategy, but the 
federal government still seemed firmly committed to its health insurance program.

Whatever their views on the legacy of the pension debates, each member of the Pearson team was undoubtedly guided by the past experience as they confronted the new demands of health insurance. The pension debate had made it clear that, in social policy formation, the federal government should underestimate the provincial agendas at its peril, and avoid constitutional wrangles as much as possible. These lessons were not lost on the architects of national health insurance, whether at the elected or bureaucratic level. The new Assistant Deputy Minister of Finance, A. W. Johnson, a recruit from the CCF administration in Saskatchewan, had as much to do with the federal government's approach to health insurance as anyone. And in designing the approach that the Liberals would pursue, Johnson looked not just to his former experiences in Regina, but also to the lessons of the pension negotiations.

While the politicians wrangled over timing-when to begin health negotiations, when to call an election-the officials in the Department of Finance struggled to design a strategy regarding health insurance. The department was well-equipped for such investigations with seasoned deputy minister Bob Bryce at the helm, and bureaucrats Al Johnson and Tommy Shoyama of the "Saskatchewan Mafia" under him. It should not have come as a surprise, then, for Johnson to solve the riddle of "financing Medicare" but it was still "the kind of solution that, once you have heard it, you kick yourself for having failed to think of." 34

According to Johnson, the manner in which the federal government had approached social policy financing in the past had been found wanting from provincial perspectives. "The essential features of a sharedcost programme," he wrote to Bryce, was that

the Federal Government devises a programme and announces it (with varying degrees of advance consultation with the provinces)...; the participating provinces sign an agreement which provides for federal cost-sharing payments to them in return for undertaking to administer a programme which conforms with certain conditions...; the programme is administered by the provinces...; [compensation] takes the form of Federal payments to the provinces...; the Federal government does a programme and a financial audit to ensure that the agreement is being adhered to...; sanctions are imposed by the Federal Government if it discovers the provinces are not adhering to the conditions spelled out in the agreement; [and finally] citizens of non-participating provinces are taxed to finance the programme in the same way as are the citizens of the participating provinces.

Each of the provinces had, at one time or another, been critical of "the unilateral federal initiative, the detailed conditions of the agreement, the detail of the audits, and the imposition of sanctions on the basis of 
Federal judgment alone." 35 The pension negotiations had tapped into some of this latent provincial discontent with the federal government's approach to social policy.

Johnson had an alternative, however. Instead of the complicated mechanism that had been employed in the past, he proposed that the provinces "not be required to sign an agreement; instead they would simply have to enact legislation which established a plan in conformity with the principles enunciated by the Federal Government after, and as a consequence of, consultation with the provinces." 36 Bryce had a few comments, in particular regarding how this system would work in concert with a formula for equalization, but in essence, this was to be the federal approach to health insurance: establish principles, and partially fund the program if provincial governments enacted legislation conforming to those principles. In its very simplicity, it promised to avoid the confrontations that characterized the pension negotiations.

The health principles that the Liberals offered had also evolved markedly since they were discussed at the Kingston Conference, and had become clear and straightforward. At the first ministers meeting called for mid-July 1965, following cabinet's approval, Pearson unveiled the federal offer. Pass legislation that establishes an insurance scheme that covers a comprehensive range of physicians' services, is universal in its coverage, is publicly administered, and is portable, and the federal government will pay half of the national cost of covering such programs. ${ }^{37}$ The provinces were left to consider the federal proposal. It was the first time since taking office that the national Liberals had acted in a calm, confident manner with regards to the provinces; it had taken years of discussion to get to this point, but by the summer of 1965, Pearson's team was ready to take on national health insurance. Shortly thereafter, he was also ready to take on the Conservatives, and called an election for the fall.

The man most responsible for the election timing was Walter Gordon, Chair of the Campaign Committee, and ever-weakening Finance Minister. He wanted an election in order to rid the current Parliament of all those who were unconvinced of the necessity of an expanding social welfare net. The problem was, however, that when the Liberals were returned with another minority government, the conservatives in the Party were even more powerful. And Gordon, who accepted responsibility for the poor electoral showing, was even weaker. He offered the Prime Minister his resignation from cabinet, which Pearson felt he had "no choice but [to] accept." 38 This unexpected shift in fortunes, this reversal of the relative power of the left and the right of the Liberal party, had important consequences for the achievement of Medicare. Despite having announced a strategy that was simple, straightforward and in many ways unassailable, the rise to prominence of more fiscally conservative 
Liberals-like Mitchell Sharp-gave reluctant provinces-like Ontarioa chance to stymie the achievement of the plan as it had been originally conceived.

With its own health insurance system already in place, the government of Saskatchewan was the only one that stood to gain immediately from the implementation of the national scheme. Other provinces were thus in a far better position to influence the final shape that Medicare would take. In Ontario, for example, two or three meetings occurred each week to discuss the developments on the federal front and to hash out a provincial response. At first, what appeared to be federal resolve put the provincial politicians in a difficult position as far as establishing an alternative. Premier John Robarts worried that "Ontario was in a delicate position. Because of the November 8th Federal election," he warned, "the Federal Government might want to jockey Ontario into a position of opposing Medicare." 39 Provincial Health Minister Matthew Dymond focused his objections on the fact that TB sanatoria and mental health facilities seemed to be excluded from the federal offer. Chief Economist Ian Macdonald pointed to the need to "treat Medicare costs as part of the overall picture of health costs" when calculating the federal financial contribution. ${ }^{40}$ But no one suggested chipping away at the actual conditions laid down by Ottawa.

The new post-1965 Liberal government had some new faces in the relevant departments, but in the early months there seemed to be little indication that the commitment to Medicare was waning. Although Judy LaMarsh was demoted from Health and Welfare to Secretary of State, the new minister responsible for seeing Medicare to conclusion was Allan MacEachen, a left-leaning Liberal who appeared in favour of the program as it had been designed. Putting Mitchell Sharp in Finance and Robert Winters in Trade and Commerce suggested a shift to the right in money matters, but in terms of the cabinet's commitment to Medicare in 1965, there seemed little evidence of this conservatism. Regardless of what was happening around the cabinet table, however, following the November election the door seemed to open for provincial critiques of the national Medicare proposals. Sensing weakness in Ottawa, or at least a wavering of support for health insurance as the old reforming power horses of the Liberal party slipped away, provincial premiers and health ministers went on the offensive.

The election of the Union Nationale in Quebec in 1966 immediately unsettled intergovernmental relations, if only because Premier Daniel Johnson was an unknown quantity. But both old and new alike chimed in with complaints about the federal Medical Care Act. When the premiers met at their annual interprovincial conference in the summer of 1966, they agreed to "request a Federal-Provincial Conference, at the top level, on Medicare.... This matter should be dealt with as a financial 
question in conjunction with the whole matter of federal-provincial financial arrangements." 41 What this meant from Ontario's perspective was that "the provinces are not in a position to embark on major new expenditure programs next year." Thus, while meeting the federal target date of 1 July 1967 for passing health insurance legislation would "be premature," it was still hoped "that a clear agreement should be reached on the targets for federal and provincial participation in Medicare schemes during the course of the five year period." 42 When, by mid-1966, provinces still had not announced their intention of legislating on full health insurance, it appeared that there were shortcomings with the federal criteria. More time would be needed, according to the bureaucrats in Finance and happily endorsed by their minister, to bring the provinces on side. ${ }^{43}$ The start date for Medicare in Canada was delayed until 1 July 1968.

This delay indicated a weakening of the federal resolve, and the provinces became even more critical of the federal proposal. Ontario openly condemned the federal role in subverting provincial priorities. According to provincial Finance Minister Charles MacNaughton, "further improvements in provincial medical care programmes should have lower priority than housing, education and urban development. If the Federal Government is prepared to make financial contributions to the provinces toward the financing of medical care, Ontario should be able to apply its share of such federal contributions to housing." Finance ministers from all of the other provinces-including Saskatchewanvoiced concerns about the costs of introducing legislation. There might be "political" support for health insurance, but provincial treasuries were already running low. ${ }^{44}$ The continuing debate within the federal cabinet on whether to press ahead with the already-revised start date of 1 July 1968 gave cash-poor provincial premiers an opportunity to raise serious questions about the cost, constitutionality, and precedent of a national health insurance program.

Pearson's 1965 cabinet was very different than the group of ministers he had gathered around him in 1963. They might not have immediately pounced on Medicare, but with a declining economic outlook, it was destined to be one of the first policies to be questioned. Just a year into the second minority government, Liberal fortunes seemed to be falling, in part because it had lost touch with its own "progressive wing." Gordon was invited to return to cabinet to try to address these issues, but before he agreed to do so, he secured Sharp's agreement that they would discuss issues in advance and attempt to minimize disagreements in cabinet. ${ }^{45}$ It was clear that Sharp was the cabinet colleague most likely to present difficulties for the left-leaning Gordon. However careful the preparatory work, Gordon did not function well in the new environment. By the fall of 1967, he was complaining that "the Liberal Govern- 
ment has given the impression of becoming increasingly conservative in its attitudes. In the process, we have given the public a confused impression of what we stand for. The more conservative elements in the cabinet, both because of their numbers and the portfolios they hold, exert a dominating influence, one that tends to be deadening and unimaginative." 46 The cabinet was rapidly moving towards a crisis. Those who counselled delay-and potentially even elimination-of the federal Medicare scheme were led by Sharp; both Gordon and MacEachen were reported to be "insisting that there can be no delay." 47 With "conflicting and contradictory statements" circulating about the future of Medicare, it was looking like it would be one of the first casualties of the battle in cabinet. 48

Finally, the Prime Minister himself stepped in. Calling for an end to cabinet wrangling, Pearson pressed for a decision on health insurance in January 1968. There was an extended cabinet debate on the pros and cons of proceeding with a 1 July 1968 start date for the Medical Care Act, during which cabinet ministers on both the left and the right weighed in with their thoughts. Sharp took the opportunity to explain that had a commitment not been made to Medicare, "he would be strongly opposed to going ahead" at the present time. He raised the fact that when the commitment to health insurance had been made, the economy was considerably brighter than it was in the winter of 1968 . He left little doubt that his vote would be cast against doggedly sticking to the 1968 deadline ${ }^{49}$ Others, including Walter Gordon, Manpower and Immigration Minister Jean Marchand, Allan MacEachen, and Treasury Board President Edgar Benson, were equally determined to follow through on the federal government's commitment. ${ }^{50}$ When a decision was finally reached in the next day or two, the 1968 deadline remained. On which side the Prime Minister had cast his vote remains unclear: "while noting that all members of the government would be expected to support the government's position unequivocally," the cabinet minutes note, "the Prime Minister expressed regret at the failure of some Ministers to be more flexible with regard to a formula for phasing-in the Medicare program, or for otherwise obtaining more provincial participation."52 Regardless of the internal divisions and provincial criticisms, however, the criteria for federal funding remained the same as had been conceived by Al Johnson. There had been moments when it seemed certain that health insurance would again be shelved by the Liberals, but there was to be no repeat of a half-century earlier. Once the provinces slowly came on board, national health insurance had become a reality.

The most important factors in the achievement of national health insurance could be found within the Liberal Party itself. Having first established the desire to enter into this new field of social policy-a desire, admittedly, borne out of electoral necessity-the Liberals then 
looked to their own past in shaping their approach to the implementation of health insurance. What lessons could be gleaned from the exhausting process of negotiating a national contributory pension scheme? As it happened, the experience of dealing with the provinces over pensions proved crucial in designing a strategy for dealing with health. The last hurdle was an internal one, as more fiscally cautious Liberals rose to positions of power in cabinet, leaving the social policy planners weakened. But when the Prime Minister announced that Medicare was to commence forthwith, the way was finally clear. Dealing with their own strengths and weaknesses, their own angels and albatrosses, both inside and outside the party, proved to be the central challenge for the Liberals in the achievement of a system of national health insurance.

\section{NOTES}

1 See Harley Dickinson, "The Struggle for State Health Insurance: Reconsidering the Role of Saskatchewan Farmers," Studies in Political Economy, 41 (Summer 1993): 133-56; Joan Feather, "Impact of the Swift Current Health Region: Experiment or Model?" Prairie Forum, 16, 2 (Fall 1991): p. 225-48; Aleck Ostry, "Prelude to Medicare: Institutional Change and Continuity in Saskatchewan, 1944-1962," Prairie Forum, 20, 1 (Spring 1995): p. 87-105; Robin F. Badgley and Samuel Wolfe, Doctors' Strike: Medical Care and Conflict in Saskatchewan (Toronto: Macmillan, 1967); E. A. Tollefson, Bitter Medicine: The Saskatchewan Medicare Feud (Saskatoon: Modern Press, 1963); and C. Stuart Houston, Steps on the Road to Medicare: Why Saskatchewan Led the Way (Montreal and Kingston: McGill-Queen's University Press, 2002).

2 J. L. Granatstein, Canada: 1957-1967: The Years of Uncertainty and Innovation (Toronto: McClelland and Stewart, 1986), p. 169-97; and Malcolm G. Taylor, Health Insurance and Canadian Public Policy: The Seven Decisions That Created the Canadian Health Insurance System and Their Outcomes, $2 \mathrm{~d}$ ed. (Montreal and Kingston: McGill-Queen's University Press, 1987), p. 69-104, 239-330.

3 Alvin Finkel, Social Policy and Practice in Canada: A History (Waterloo: Wilfrid Laurier University Press, 2006), p. 105.

4 C. David Naylor, Private Practice, Public Payment: Canadian Medicine and the Politics of Health Insurance, 1911-1966 (Kingston and Montreal: McGill-Queen's University Press, 1986), p. 31-32.

5 Naylor, Private Practice, p. 58-89.

6 Report of the Royal Commission on Dominion-Provincial Relations; for a recent evaluation of the working of the commission, see Barry Ferguson and Robert Wardhaugh, "Impossible Conditions of Inequality': John W. Dafoe, the Rowell-Sirois Royal Commission, and the Interpretation of Canadian Federalism," Canadian Historical Review, 84, 4 (December 2003): 551-83.

7 P. E. Bryden, Planners and Politicians: Liberal Politics and Social Policy, 1957-1968 (Montreal and Kingston: McGill-Queen's University Press, 1997), p. 4-5.

8 See Alvin Finkel, "Paradise Postponed: A Re-examination of the Green Book Proposals of 1945," Journal of the Canadian Historical Association, new series, Vol. 4 (Ottawa 1993), p. 120-42; Marc J. Gotlieb, "George Drew and the DominionProvincial Conference on Reconstruction, 1945-46," Canadian Historical Review, 66, 1 (1985): 27-47; and P. E. Bryden, "Beyond the Green Book: Ontario's Approach to Intergovernmental Negotiations, 1945-1955," in Nancy Christie and Michael Gauvreau, eds., Cultures of Citizenship in Post-war Canada, 1940-1955 (Montreal and Kingston: McGill-Queen's University Press, 2003), p. 133-62. 
9 On these developments, see Paul Martin, A Very Public Life: Volume II: So Many Worlds (Toronto: Deneau, 1985), p. 27-75.

10 Opening Statement by Leslie Frost, Canada, Federal-Provincial Conference, 1955: Preliminary Meeting (Ottawa: Queen's Printer, 1955), p. 19.

11 Taylor, Health Insurance and Canadian Public Policy, p. 105-60.

12 On the Hall Commission, see Frederick Vaughn, Aggressive in Pursuit: The Life of Justice Emmett Hall (Toronto: The Osgoode Society for Legal History, 2004), esp. chap. 5; and Dennis Gruending, Emmett Hall: Establishment Radical (Toronto: Macmillan, 1985).

13 Queen's University Archives (QUA), Tom Kent Papers, Box 6, File: Study Conference, September 1960. "Study Conference on National Problems," 29 June 1960.

14 QUA, Kent Papers, Box 6, File: Study Conference, September 1960, "Study Conference on National Problems," 29 June 1960.

15 Library and Archives Canada (LAC), Lionel Chevrier Papers, MG 32 B16, Vol. 12, File: Nat'1 Problems, 1. J. Wendell Macleod, "Basic Issues in Hospital and Medical Care Insurance," Queen's University, 6-10 September 1960.

16 Tom Kent, A Public Purpose: An Experience of Liberal Opposition and Canadian Government (Kingston and Montreal: McGill-Queen's University Press, 1988), p. 82-83.

17 QUA, Kent Papers, Box 6, File: Study conference, September 1960. R. M. MacIntosh, "The Kingston Conference," 4 October 1960.

18 LAC, Lester B. Pearson Papers, MG 26 N2, Vol. 27 File: 391-National Rally. Walter Gordon to Boyd Upper, 24 April 1961.

19 QUA, Kent Papers, Box 1, File: Correspondence, September to December 1960. Gordon to Kent, 4 October 1960.

20 LAC, National Liberal Federation Papers, MG 28 IV 3, Vol. 889, File: Health Insurance. "Plan for Health," Liberal Rally statement, January 1961.

21 LAC, Pearson Papers, MG 26 N2, Vol. 114, File: Liberal Health Plan. Pearson to Boyd Upper, 7 February 1961.

22 LAC, Pearson Papers, MG 26 N2, Vol. 27, File: 391-National Rally, Upper to Walter Gordon, 30 March 1961.

23 LAC, Pearson Papers, MG 26 N2, Vol. 114, File: Liberal Health Plan. Kent to Upper, 15 February 1961.

24 LAC, Pearson Papers, MG 26 N5, Vol. 46, File: Pearson Years, Rolls 113-118; Pearson interview with Chris Young, 11 June 1970, Roll 115. See also Tom Kent, "Reformism," in Norman Hillmer, ed., Pearson: The Unlikely Gladiator (Montreal and Kingston: McGill-Queen's University Press, 1999), p. 168-71.

25 LAC, Peter Stursberg Papers, Vol. 15, File: LaMarsh, Judy. Interview, 28 May 1975.

26 QUA, Kent Papers, Box 2, File: correspondence, June 1963. Robarts to Pearson, 6 February 1962.

27 Archives of Ontario (AO), George Gathercole Papers, MU 5332, File: Portable Pension Correspondence. Gathercole to J. J. Connolly, 1 May 1963.

28 See, for example, Claude Morin, Quebec versus Ottawa: The Struggle for SelfGovernment, 1960-1972 (Toronto: University of Toronto Press, 1972); and Kenneth Bryden, Old Age Pensions and Policy-Making in Canada (Kingston and Montreal: McGill-Queen's University Press, 1974).

29 QUA, Kent Papers, Box 3, File: 1-12 October 1965. Kent to Pearson, 5 October 1965.

30 LAC, Walter Gordon Papers, MG 32 B44, Volume 16, File: 11. Gordon to Pearson, 27 January 1965.

31 LAC, Gordon Papers, Vol. 16, File: 11. Gordon to Pearson, 30 June 1965.

32 LAC, Department of National Health and Welfare Papers, RG 29, Vol. 1058, File: 500 1-12, Pt. 3. LaMarsh to Provincial Ministers of Health, 9 April 1965.

33 LAC, Privy Council Office Papers, RG 2, Series A-5-a, Vol. 6271, Cabinet conclusions, 7 July 1965.

34 Kent, A Public Purpose, p. 366. 
35 LAC, Department of Finance Papers, RG 19, Vol. 4854, File 5508-02. Pt. 1, Johnson to Bryce, 16 July 1965.

36 Department of Finance Papers, Vol. 4854, File 5508-02, Pt. 1. Johnson to Bryce, 16 July 1965.

37 AO, Robarts Papers, RG 3 Series A-13-1, Box 134, File: Medical Insurance, Health, January-December 1966. "Implementation of the Medical Services Insurance Act in the Light of the Proposals Made at the Federal-Provincial Conference, July 1965."

38 LAC, Gordon Papers, Vol. 16, File: 11. Gordon to Pearson, 9 November 1965 and Pearson to Gordon, 11 November 1965.

39 AO, Robarts Papers, RG 3-26, Box 492, File: Federal-Provincial Conference of Ministers of Health, Federal Government, 23 and 24 September 1965. "Meeting re: Medicare Conference of Federal and Provincial Ministers of Health," 14 September 1965.

40 AO, Robarts Papers, RG 3-26, Box 492, File: Federal-Provincial Conference of Ministers of Health, Federal Government, 23 and 24 September1965. "Meeting re: Medicare Conference of Federal and Provincial Ministers of Health," 14 September 1965.

41 AO, RG 50-33, Box 10, File: 1966 F-P Tax Agreements-General File. "Seventh Provincial Premiers Conference," HI Macdonald to D. W. Stevenson and Robarts, 4 August 1966.

42 AO, Robarts Papers, RG 3-26, Box 122, File: Minister, Health, January 1966 December 1966. Don Stevenson, "Proposal Regarding Ontario's Stand on Medicare," 24 August 1966.

43 Mitchell Sharp, Which Reminds Me...: A Memoir (Toronto: University of Toronto Press, 1994), p. 149.

44 LAC, Gordon Papers, Vol. 16, File: 13. "Summary of Views Expressed by Provincial Ministers of Finance on the Subject of Medicare at the 16-17 November Meeting of Finance Ministers," Cabinet Document \#761/67.

45 LAC, Gordon Papers, Vol. 16, File: LBP, "Note of matters to discuss with Mike on 29 December 1966" and Confidential Memo to file, 4 January 1967.

46 LAC, Gordon Papers, Vol. 16, File: 13: "The position of the government at the present time," 3 October 1967.

47 "Cabinet finds last cuts hardest," Globe and Mail, 25 October 1967.

48 J. L. Granatstein Xerox collection, Walter Gordon Papers, "Notes for a discussion at Cabinet," Tuesday, 24 October 1967.

49 LAC, Privy Council Office Papers, Series A-5-a, Vol. 6338, Cabinet Minutes, 30 January 1968.

50 Granatstein Xerox collection, Gordon Papers, "Re: The Book-Sharp Troubles," 8 March 1968.

51 LAC, Privy Council Office Papers, Series A-5-a, Vol. 6338, Cabinet Minutes, 1 February 1968. 